NBER WORKING PAPER SERIES

\title{
THE GEOGRAPHY OF STOCK MARKET PARTICIPATION: THE INFLUENCE OF COMMUNITIES AND LOCAL FIRMS
}

\author{
Jeffrey R. Brown \\ Zoran Ivković \\ Paul A. Smith \\ Scott J. Weisbenner \\ Working Paper 10235 \\ http://www.nber.org/papers/w10235 \\ NATIONAL BUREAU OF ECONOMIC RESEARCH \\ 1050 Massachusetts Avenue \\ Cambridge, MA 02138 \\ January 2004
}

We thank Jim Cilke for assistance with the tax data and Jean Roth of the NBER for assistance with the 1990 Census data. We thank Josh Coval, Jeff Kubik, Michael Palumbo, and Mike Weisbach for helpful comments. The analysis for this paper was completed while Paul Smith was an economist with the Office of Tax Analysis at the U.S. Department of Treasury. The views expressed herein are those of the authors and not necessarily those of the National Bureau of Economic Research.

C2004 by Jeffrey R. Brown, Zoran Ivković, Paul A. Smith, and Scott J. Weisbenner. All rights reserved. Short sections of text, not to exceed two paragraphs, may be quoted without explicit permission provided that full credit, including (C) notice, is given to the source. 
The Geography of Stock Market Participation: The Influence of Communities and Local Firms Jeffrey R. Brown, Zoran Ivković, Paul A. Smith, and Scott J. Weisbenner NBER Working Paper No. 10235

January 2004

JEL No. G0, G11

\begin{abstract}
This paper is the first to investigate the importance of geography in explaining equity market participation. We provide evidence to support two distinct local area effects. The first is a community ownership effect, that is, individuals are influenced by the investment behavior of members of their community. Specifically, a ten percentage-point increase in equity market participation of the members of one's community makes it two percentage points more likely that the individual will invest in stocks. We find further evidence that the influence of community members is strongest for less financially sophisticated households and strongest within "peer groups" as defined by age and income categories. The second is that proximity to publicly-traded firms also increases equity market participation. In particular, the presence of publicly-traded firms within 50 miles and the share of U.S. market value headquartered within the community are significantly correlated with equity ownership of individuals. These results are quite robust, holding up in the presence of a wide range of individual and community controls, instrumental variables estimation, the inclusion of individual fixed effects, and specification checks to rule out that the relations are driven solely by ownership of the stock of one's employer.

Jeffrey R. Brown

University of Illinois at Urbana-Champaign

340 Wohlers Hall MC-706

Champaign, IL 61820

and NBER

brownjr@uiuc.edu

Zoran Ivković

University of Illinois at Urbana-Champaign

340 Wohlers Hall MC-706

Champaign, IL 61820

ivkovich@uiuc.edu

Paul A. Smith

Federal Reserve Board of Governors

Washington, DC 20551

paul.a.smith@frb.gov

Scott Weisbenner

University of Illinois at Urbana-Champaign

340 Wohlers Hall MC-706

Champaign, IL 61820

and NBER

weisbenn@uiuc.edu
\end{abstract}




\section{Introduction}

What influences a household's decision to participate in the stock market? Only one-half of U.S. households invest in the stock market, and an even smaller fraction, fewer than 30 percent, hold stocks or mutual funds outside of retirement plans. ${ }^{1}$ There are many reasons why the determinants of stock market participation are of interest to researchers and policy makers. The most obvious is that portfolio allocation can be an important determinant of wealth and wellbeing. As a result of the significant equity premium over the past century [Mehra and Prescott 1985, Fama and French 2002], individuals who participated in the stock market, on average, increased their risk but were able to accumulate significantly more wealth than individuals who did not, holding fixed their level of active saving. As a result, participation in equity markets can have a substantial effect on lifetime consumption patterns. Second, as discussed by Mankiw and Zeldes [1991], Heaton and Lucas [2000], and Brav, Constantinides, and Gezcy [2002], the rate of equity market participation can, in turn, affect the level of the equity premium itself.

The rate of stock market participation is also important for public policy. For example, the fact that a large share of households has no equity market exposure played a role in the recent debate over the distributional effects of lowering the tax rate on capital gains and dividends [Friedman and Greenstein 2003]. Also, proponents of including personal accounts in the Social Security system often suggest that a benefit of doing so is to expand equity ownership to all households. Moreover, the presence of equity market non-participants means that investing Social Security surpluses in private investments can have real effects on the economy [Abel 2001, Diamond and Geanakoplos 2003].

\footnotetext{
${ }^{1}$ These figures are based on authors' tabulations from the 1998 Survey of Consumer Finances, and are consistent with other published estimates using these sources, such as Bertaut \& Starr-McCluer (2000). Moreover, Aizcorbe, Kennickell, and Moore (2003) report similar findings.
} 
In very simple models of portfolio choice, it is easy to show that even extremely risk averse investors should place at least a small portion of their assets in stocks [e.g., Mas-Colell, Whinston, and Green 1995]. However, there are many cases in which non-participation may be rational. First, given the presence of means-tested social insurance programs, many households may find it optimal not to save at all [Hubbard, Skinner and Zeldes 1995, Scholz, Seshardi, and Khitatrakun 2003]. Second, even among those who save, there may be fixed costs of investing in equity markets that make it rational for many individuals not to participate. For example, Vissing-Jorgensen [1999] finds that a fixed cost of equity market participation as low as \$200 would be sufficient to lead to currently observed rates of non-participation. Some of these fixed costs may be psychological, that is, the need to educate oneself about how markets work, how to invest, and so forth. Studies have documented that equity market participation rates do vary with demographic characteristics. For example, it is known that stock market participation increases with income, age and wealth, and that men are more likely to participate than women [Poterba and Samwick 1999].

This paper presents what we believe is the first evidence on the importance of two geographic effects on equity market participation. The first factor, the "community effect," is that an individual is more likely to participate in the stock market when a higher fraction of individuals in the local community (households residing within 50 miles) are stock market investors. Based on a large, nationally representative panel data set of 88,000 taxpayers over a period of 10 years (for a total of over 750,000 taxpayer-year observations), we provide a central estimate that a 10 percentage point increase in stock ownership in the community increases the probability that an individual participates in the equity market by 2 percentage points, or an increase of more than 6 percent relative to baseline ownership rates. We also provide evidence 
that this effect is strongest for less financially sophisticated households, and that households are more affected by the participation decision of individuals who are "more similar" (in terms of age and income) to themselves.

The second factor, the "local firm effect," is that an individual's propensity to buy stocks is positively influenced by the presence of local, publicly-traded firms in the community. For example, the mere presence of at least one publicly-traded firm in the community (that is, at least one firm is headquartered within 50 miles) increases the likelihood of participation by one percentage point. From there, a five-percentage point increase in the share of total U.S. market capitalization headquartered in the community (i.e., roughly a one standard deviation change) increases the likelihood of participation by an additional percentage point.

Recognizing that the location of a household is not randomly assigned, we subject these findings to a wide range of robustness checks and find that the effects are quite persistent. We find evidence of community ownership effects and local firm effects even after including an extremely rich set of individual and zip code level covariates, implementing an instrumental variables strategy, and even controlling for individual fixed effects.

There are many reasons to suspect that the equity market participation rate of one's community may influence one's own decision. First, Hong, Kubik, and Stein [2004] present a model in which stock market participation may be influenced by social interaction. Such social interaction can serve as a mechanism for information exchange via "word-of-mouth" and/or “observational learning” [Banerjee 1992, Ellison and Fudenberg 1993, 1995]. Put simply, many individuals may find it easier to learn how to open up a mutual fund or brokerage account by talking to their friends than through other mechanisms. Second, as also noted by Hong, Kubik, and Stein [2004], individuals may simply enjoy discussing the ups and downs of stock market 
investments with their friends and colleagues and are thus more apt to participate in the stock market if there is a high participation rate among their friends and colleagues. Third, according to Bernheim's [1994] model of conformity individuals may wish to maintain the same consumption of their social group does. Thus, participation in the stock market by their social group would have a positive influence on their own decision to do so. This effect could also be generated by external habit formation models [Campbell and Cochrane 1999, Shore and White 2003] or the scarcity of local resources that lead investors to care about their relative wealth in the community [DeMarzo, Kaniel and Kremer 2002].

There is a significant body of research documenting the empirical relevance of "neighborhood effects," or "peer effects," in wide variety of settings, ranging from outcomes for disadvantaged youth [Case and Katz 1991] to crime [Glaeser, Sacerdote and Scheinkman 1996]. In the specific context of financial behavior, Duflo and Saez [2002, 2003] show how the decision by one's co-workers to participate in tax-deferred savings plans affects one's own participation decision. Hong, Kubik, and Stein [2004] show that more "social" individuals, namely those who interact frequently with neighbors or attend church, are more likely to participate in equity markets. While Hong, Kubik, and Stein show that the effect of "sociability" on the participation decision is stronger in states with high rates of participation, our paper, to our knowledge, is the first to provide direct empirical evidence on the importance of the equity market participation rate of one's community on an individual's own participation decision. Furthermore, our panel data gives us an advantage in that we can use household fixed effects to control for unobservable household characteristics that may spuriously drive such a relation in a cross-sectional setting.

The second effect we report in this paper, namely that a stronger presence of publiclytraded firms in one's community increases the probability of equity market participation, is 
motivated by a growing literature on the importance of local firm effects in other financial contexts. Several papers provide evidence that individual investors prefer "familiar," or local, investments. For example, we know that, around the world, investors have a "home equity bias" [French and Poterba 1991]. Participants in 401(k) plans show a strong tendency to overweight own-company stock in their portfolios [Benartzi 2001, Liang and Weisbenner 2002, Mitchell and Utkus 2002]. Huberman [2001], Grinblatt and Keloharju [2000], Zhu [2002], and Ivković \& Weisbenner [2003] document individual investor preferences for local stocks. While some of this local preference may simply reflect a behavioral bias for "familiarity," mounting evidence supports the idea that some of this behavior is information-based. For example, Coval and Moskowitz [1999, 2001] demonstrate that professional money managers lean toward local stocks and that their local investments outperform their investments made in more distant firms. At the individual level, Ivković and Weisbenner [2003] show that individuals investors at a retail discount brokerage firm have a strong preference for local investment and that households generate an additional return of $3.2 \%$ annually from their local versus non-local investments.

This paper provides the first evidence that the presence of local firms also has a quantitatively important influence on the probability of participating in the stock market. There are two classes of reasons why local firm presence may matter. The first is simple familiarity. Firms "make their presence known" in their home community in many ways, either directly (e.g., sponsoring community events) or indirectly (e.g., firm's presence is learned via social interaction with employees of the firm). Second, the presence of local firms is likely to lead to an increased flow of information, such as stories in the local paper or television news about details of a company's business, as well as more attention paid to the stock market in general. In either case, familiarity or knowledge about a particular company may make it more likely that an individual 
will choose to get involved in the stock market, particularly given the possibility that this local knowledge may give an investor the ability to earn returns superior to those they would likely earn from investing in non-local companies [Ivković and Weisbenner 2003].

This paper proceeds as follows. In Section 2 we introduce the data set. Section 3 provides initial results on the "traditional" determinants of equity market participation such as demographic and financial characteristics. In Section 4, we present our results showing the effect of community stock market participation and local firm presence. Section 5 concludes.

\section{The Data}

\section{A. The Panel of U.S. Taxpayers}

To conduct a nationally representative study of how individual equity market participation decisions are influenced by geographic factors such as community equity market participation and firm presence, it is necessary to have a very large, nationally representative dataset containing many observations for each "community." To the extent that the "community effect" is based on an individual's interactions with friends, neighbors and co-workers, it is important to choose a geographic size that is large enough to capture most of the individuals in a person's social group, but not so large as to completely dilute these effects. Most standard micro data sets are not well suited for this task. For example, the Survey of Consumer Finances (SCF), arguably the best available, nationally representative study for examining household financial decision making, is a cross-sectional study with only approximately 5,000 observations. The Health and Retirement Study, which offers the potential advantage of being a panel study, is 
only slightly larger than the SCF and focuses only on particular cohorts nearing or in retirement. ${ }^{2}$

Similar problems are associated with most other standard household data sets.

Our primary source of data is a large panel of tax returns covering the years 1987 to 1996. ${ }^{3}$ The panel is based on the IRS's annual cross-sectional sample of tax returns, which are large samples chosen to represent the population of tax-return filers. The population of tax filers is similar to the population of households, except that a household may comprise more than one tax-filing unit (e.g., dependents may file their own returns), and some households do not file any tax returns. ${ }^{4}$ For example, our data for 1994 represent about 130 million tax returns, while the 1995 SCF (covering the year 1994) represents about 100 million households. Throughout the paper we use the terms individuals, households, and taxpayers interchangeably, but strictly speaking, the unit of observation for this data set is the taxpayer.

The annual IRS cross-sections are stratified samples, with the probability of inclusion rising steeply with total income. ${ }^{5}$ Variables include most of the values from the 1040 tax form and associated schedules, as well as data matched from Social Security records, such as the age and gender of each individual represented on the return. ${ }^{6}$ The 1987 cross-section sample of about 88,000 returns is the base year of the panel. The panel was constructed by matching, in each subsequent year, the full population of tax returns for the Social Security numbers of all taxpayers, spouses, and dependents that appeared in the 1987 sample. This method allows

\footnotetext{
${ }^{2}$ The original HRS survey, fielded in 1992, consisted of approximately 7,500 households with at least one member born between 1931 and 1941. In later waves of the survey, additional cohorts have been added, but in no case does it contain households below 50 years of age.

${ }^{3}$ The panel was developed as a joint effort between the Treasury Department's Office of Tax Analysis and the IRS's Statistics of Income division. The panel uses confidential records and is not publicly available.

${ }^{4}$ Low-income households are not required to file returns (but many do so in order to claim a refund of overwithholding or a refundable tax credit such as the EITC). In 1987, the filing threshold ranged from $\$ 4,400$ to $\$ 10,000$, depending on age and filing status.

${ }^{5}$ We use sampling weights, defined as the inverse probability of selection, when reporting all tabulations and descriptive statistics.

${ }^{6}$ Further details on the construction of the tax data are available in Amromin \& Smith (2003).
} 
individuals to be tracked over time regardless of income changes, marriage, divorce, or establishment of a new tax unit by a former dependent. ${ }^{7}$

To simplify the analysis, we exclude married couples filing separate returns and restrict the analysis to taxpayers who were primary filers in 1987. This reduces the sample to 767,295 tax returns over the ten-year period. Another important advantage of the tax data is that it contains very precise geographical identifiers (i.e., zip codes) that can be used to create our geographic measures of interest. We are able to match the zip code reported on the tax return with a location (i.e., latitude and longitude) for 753,103 observations.

While tax data has many advantages, its traditional disadvantage for many purposes is that it contains less information about non-financial demographic characteristics, such as race, ethnicity, occupation and industry. To address this concern, we merge a wide range of Census data by zip code. As a result, while we do not know, for example, the race of a particular taxpayer, we do know the racial composition of the zip code in which the taxpayer resides. The same is true of other pertinent characteristics.

\section{B. Measuring Equity Ownership}

Naturally, to conduct a study on the determinants of equity market participation, it is necessary to have a good measure of whether an individual owns stock. Because it is not necessary for the IRS to know stock ownership for tax purposes, the tax return does not provide direct information about stock ownership. Nevertheless, we are able to proxy for equity

\footnotetext{
${ }^{7}$ As a result of this sampling methodology, our sample is not subject to sample attrition bias that sometimes afflicts panel studies using survey data. There is, however, attrition from the population of tax filers that occurs when a filer's income drops below the filing threshold. This source of attrition is non-random - older and lower-income workers are more likely to drop out of the filing population than middle-aged, higher-income workers. Using data from the Survey of Consumer Finances, we have found that the fraction of non-filers who own equities in a nonretirement account is only $2-4 \%$ over the period $1989-1998$.
} 
ownership using the appearance of dividend income and/or capital gains on the tax return. Given our reliance on tax return data to infer stock market participation, we will miss people who only invest in stocks or equity mutual funds in non-taxable (i.e., retirement) accounts. Thus, when we refer to equity market participation throughout the paper, we are specifically referring to stock or equity mutual fund ownership in one's taxable account (i.e., outside of retirement plans).

The dividends measure will capture all dividends paid out on stock and dividends paid through taxable mutual funds. There are two reasons why this proxy is imperfect. First, dividend income as reported on a tax return includes payouts from any mutual fund, even if the fund is exclusively invested, for example, in fixed-income assets. Second, while dividends will capture equity ownership for those who invest in dividend-paying firms, it may miss those who invest primarily in non-dividend paying firms, such as those in the technology sector that became increasingly important during the 1990s. A second measure is realized capital gains. This would capture stockholders who sell shares of a stock or a mutual fund, whether at a gain or a loss. Of course, capital gains will also capture the gains from the sale of other, non-stock assets, such as investment real estate or collectibles. The third potential measure of stock ownership is to combine the first two, defining someone as a stockowner if they report dividends and/or capital gains.

Because of the potential for both type 1 and type 2 errors in defining equity ownership, a natural first question to ask is whether our measures really are reasonable proxies for actual equity ownership. The Survey of Consumer Finances allows us to address this concern, and the results clearly indicate that they are good proxies. Table 1 reports the correlation between actual equity ownership (i.e., equity ownership outside of retirement plans) as reported by SCF respondents and whether these same households reported dividends and capital gains on their tax 
return in the previous year. The correlations are quite high, averaging 0.62 for dividends, 0.47 for capital gains, and 0.63 for the combined measure. While there is a slight downward trend in the correlations over time (more for dividends than the combined measure), the overall decline is not large and can be easily controlled for in a regression framework by using year fixed effects.

Table 2 reports the trends of equity ownership in our tax panel as measured by our reported dividend and capital gains proxies, as well the actual equity ownership rates reported in the SCF over this period. We report the SCF equity ownership rates among tax-filers to facilitate direct comparison across these two sources of data. From 1987 to 1996, the fraction of the population reporting dividends and/or capital gains rose from just over one-quarter to just over one-third of the taxpaying population. We see similar trends among dividends and capital gains separately. This is consistent with the trend in actual equity ownership, as reported in the SCF over a similar period (from 1989 to 1998, actual equity ownership rates rose from 22.2 percent to 30.5 percent). Figure 1 illustrates the growth rates in actual equity ownership as well as the equity ownership proxy (report dividend and/or capital gains on the tax return). Over the overlapping period (1989-1996), our proxy for equity ownership increased by $22 \%$, comparable to the $20 \%$ increase in actual equity ownership.

\section{Defining "Community"}

We define the geographic span of a community as a circle around a household with a 50mile radius. We choose this distance for several reasons. First, we believe that 50 miles will capture the vast majority of one's social interactions, including those that are employment based. According to the 1990 Census, $88 \%$ of the population lives within 25 miles of work (98\% live within 50 miles). Of course, if two co-workers each live only 25 miles from work, the may live as many as 50 miles from one another. In considering firm locality effects, it is especially 
important not to choose an area that is too small. In essence, it is important that any firms that are likely to be prominent in the local news market and other forms of interaction with the community be included in a measure of firm locality, and 50 miles is a reasonable cut-off to capture this effect. ${ }^{8}$

Table 3 reports summary statistics for our key variables of interest, including equity market participation rates and measures of local firms. As in Table 2, the mean value of equity ownership (defined here using the combined dividend and/or capital gains measure) is approximately 30 percent. The second row of Table 3 shows the distribution of equity ownership by the 50 -mile radius communities for each of our households. Note that for each individual $i$ the 50 mile radius variable is constructed by determining what fraction of households within a 50 mile radius of individual $i$, but excluding individual $i$, own stock. At the $10^{\text {th }}$ percentile of the distribution, about 1 in 5 community households own stock, whereas this ratio rises to nearly 2 in 5 community households at the $90^{\text {th }}$ percentile.

Nearly 92 percent of households have at least one publicly-traded firm headquartered within 50 miles. $^{9}$ However, the share of total U.S. firm market value residing (i.e., headquartered) in that 50-mile radius differs substantially. To help place this in context, over the period from 1987 to $1996,0.7 \%$ of U.S. firm market value was located within 50 miles of Kansas City, MO on average (this is roughly the median value across communities), 5.6\% was located within 50 miles of Dallas, TX, 8.3\% was located within 50 miles of Chicago, and $25.8 \%$ was located within 50 miles of New York City. At the $10^{\text {th }}$ percentile of the distribution, less than $1 / 1000^{\text {th }}$ of one percent of firm value is located within 50 miles. At the $90^{\text {th }}$ percentile, 7.7

\footnotetext{
${ }^{8}$ We ran most of our base specifications using a 25 -mile radius definition, and found similar, significant results.

${ }^{9}$ Compustat provides the location of a firm's headquarters, allowing us to compute the distance between each individual taxpayer and each firm. Thus, all references to the location of a firm refer to the firm's headquarters, and not the location of its individual factories or plants.
} 
percent of total market value is located within 50 miles. The final row of Table 3 reports the distribution of population, which, not surprisingly, is significantly less concentrated than the population of firms.

\section{Demographic and Financial Determinants of Stock Market Participation}

Before testing our hypotheses of interest, it is useful first to examine how equity market participation varies with standard demographic and financial measures. Not only are these measures of potential interest in their own right, but they also serve as a rich source of controls in the specifications in which we test for geographic effects of participation and local firms.

Table 4 reports the coefficients from a simple linear probability model of individual $i$ 's stock market participation on characteristics of the individual taken from the tax return and on characteristics of the household's zip code for variables unavailable on the individual-level because they are not reported on the tax return (e.g., race). ${ }^{10}$ We use rich controls for age and income, including dummy variables for various age and income categories, as well as entering income, income squared, age, and age squared. As expected, equity ownership is strongly increasing with income and age. It is also increasing with wealth proxies. For example, households who claim a mortgage interest deduction (a proxy for home ownership), receive income from rental real estate, royalties, partnerships or S-corporations (file a schedule E), or own a defined contribution plan through work are all more likely to own equity in their nonretirement account. We also find that equity ownership is higher for the self-employed (file a schedule C) and those who are subject to the Alternative Minimum Tax. Equity market

\footnotetext{
${ }^{10}$ Throughout this paper, we report results using a simple linear probability model, so the coefficient estimates can be directly interpreted as marginal effects. An examination of the marginal effects from a non-linear probit model yields very similar results.
} 
participation is lower for single households and for those who file as a head of household (generally signifying a single parent family). Families with more dependents are also less likely to own equity, although the effect is not economically large (e.g., four additional children lowers the probability of stock ownership by only one percentage point).

We use averages across a zip code when individual-level data is not available, and these zip-code-level characteristics are also quite significant. Households in more highly educated zip codes are more likely to own stock. Households in zip codes with a higher concentration of African-American, Hispanic, or Asian households are also less likely to own stock. The mean house price in the zip code is insignificant. We also find lower levels of ownership for households in zip codes with a higher proportion of clerical workers, craftsmen, operators, and similar fields, relative to professionals. Finally, we find that a larger concentration of private sector employees is correlated with higher equity ownership, whereas households in zip codes with many local, state, and federal government employees are less likely to own stock.

\section{Testing for Geographic Effects}

We seek to test two primary hypotheses. The first is that an individual's equity market participation decision is influenced by the equity market participation of other individuals in the community. The second hypothesis is that this decision is affected by the proximity of publicly traded firms. We test for both of these effects in a regression specification that conditions on all of the variables discussed in Section 3. We are looking for community effects and local firm effects after conditioning not only on a rich set of individual demographic and financial characteristics, but also on zip-code-level controls for race, ethnicity, occupation, employment sector, and housing prices. 


\section{A. Initial Results for Community Ownership Effects}

Table 5 presents the first set of results for community effects. Columns (1) through (3) present results for regressions in which we define equity ownership as one if an individual reports dividends and/or capital gains. Columns (4) through (6) report results defining equity ownership solely based on dividends, while columns (7) through (9) use the capital gains measure. For each of these three alternative proxies for equity ownership, we first report, in columns (1), (4), and (7), our basic specification that includes all the variables from Table 4, year dummies, controls for the population of the community, and the six variables of interest whose coefficients are reported in this table. Because our sample consists of pooled observations across all years in the panel, in all regressions we adjust the standard errors for clustering on the taxpayer ID to account for correlation of the same taxpayer's equity ownership over time.

The coefficient on equity ownership in the rest of the community is highly statistically significant. ${ }^{11}$ It is also economically significant, suggesting that a 10 percentage point increase in the fraction of one's community that owns equity (e.g., moving from the $10^{\text {th }}$ percentile to the median or the median to the $90^{\text {th }}$ percentile) increases one's own probability of owning equity by 1.6 to 2.4 percentage points, depending on which equity proxy is used. From a base of 30 percent equity market participation, this is roughly a 6 percent increase over the baseline.

Despite the fact that we already have more than 50 additional control variables on the right-hand side of our regression to control for income, wealth and demographic effects, one might still argue that the community effect coefficient simply reflects the fact that people prefer to live near people who are like them. Even after controlling for own characteristics, it might be

\footnotetext{
${ }^{11}$ In all cases, the definition of community equity ownership is based on the same definition as individual ownership. Equity ownership in individual $i$ 's community is computed exclusive of individual $i$ 's own equity ownership.
} 
the case that higher income people like to live near other high-income people, and both like to own stock. To test for sensitivity to this critique, in columns (2), (5), and (8) we add as additional covariates a richer set of controls for the individual's zip code, including average income, age, filing status, number of dependents, self-employment status, and so on, among households in individual $i$ 's zip code. We find that the inclusion of these additional regressors has virtually no effect on our primary coefficient of interest. Thus, even after controlling for own characteristics and the characteristics of other individuals in the zip code, we still find a significant and robust relation between equity market participation of individuals and other residents in their community. ${ }^{12}$

Columns (3), (6), and (9) take even further these concerns about the simultaneous determination of the equity market participation of an individual and his or her community. Here, we employ an instrumental variables strategy whereby we instrument for the equity market participation rates of individuals in the 50-mile radius using the average income, age and other financial characteristics of households in the 50-mile radius. The logic of these instruments is that, conditional on own financial and demographic characteristics, and conditional on characteristics of the household's zip code, there is little reason to expect that the age or income distribution of households in the larger community should directly influence stock market participation rates of a particular household. In other words, our identification assumption is that these broad community characteristics, while highly correlated with ownership rates of the

\footnotetext{
${ }^{12}$ In Appendix Table 1, we report the coefficients on all of our individual-level and zip-code-level control variables from the regression in column (2) in Table 5. Note that, while the average income across the household's zip code is significant, the estimated effect is fairly small. For example, while having household income between $\$ 50-150 \mathrm{k}$ increases the probability of ownership by 8.1 percentage points and having household income over $\$ 150 \mathrm{k}$ increases the probability 27.3 percentage points relative to a household with low income, the comparable zip-code level controls have an effect that is only $1 / 10^{\text {th }}$ as large.
} 
community, will not be correlated with individual $i$ 's equity market participation except through the stock market participation of these other individuals. ${ }^{13}$

As the instrumental variable (I.V.) results in columns (3), (6) and (9) suggest, the I.V. approach makes virtually no difference in our coefficients of interest. If anything, the I.V. strategy increases the coefficient slightly when using capital gains as our equity ownership proxy, but the effect on the other proxies is minimal. Given that our I.V. results closely mirror our un-instrumented regression results, for the rest of this paper, we will use the middle specification (no instrumental variables, but including the full set of zip-code-level characteristics) as our base case.

\section{B. Initial Results for Local Firm Effects}

Several local firm effects are also significant. First, individuals who have at least one publicly-traded firm headquartered within 50 miles are approximately one percentage point more likely to own equities. Furthermore, as the share of the total U.S. market capitalization within an individual's community increases, the probability of owning equities increases further. For example, a five percentage point increase in the share of firm value headquartered within 50 miles, which corresponds roughly to a one standard deviation change, increases the probability of owning stocks by an additional percentage point. To put this increase in perspective, a move from Kansas City, MO (a community with roughly the median share of U.S. firms) to Dallas, TX would increase the equity ownership of a household's community by 5 percentage points (and

\footnotetext{
${ }^{13}$ Recall that our concern is that people with similar tastes for stock market participation might sort and live in the same area. Our regression already controls for demographic and financial characteristics of an individual's zip code. Thus, our I.V. strategy relies on the assumption that the effect of any sorting of similar households into the same neighborhood is picked up by the zip-code-level controls (e.g., zip-code level age and income), and with the inclusion of these finer community controls, the broader community (i.e., 50-mile radius) characteristics will not be correlated with an individual's equity ownership except through the stock market participation of other individual's within the 50-mile radius.
} 
thus would increase the likelihood that the household owns equity by $5^{*} 0.2=$ one percentage point). Similarly, a move from Kansas City to Chicago would increase the equity ownership of a household's community by 8 percentage points (and thus would increase the likelihood that the household owns equity by 1.6 percentage points), while a move from Kansas City to New York City would increase community equity ownership by 25 percentage points (and thus would increase the likelihood that the household owns equity by five percentage points). Since the regressions also include controls for the population of the community, the local firm effect is not simply reflecting a big community effect.

The equally weighted average rate of return on local firms is not significant in most of the specifications. The exception is with the dividend regressions, in which case it has a small negative effect. Given that growth stocks (which are less likely to pay dividends) outperformed value stocks (which are more likely to pay dividends) seven of the ten years from 1987-1996, local investment opportunities of the communities whose firms had a higher stock return are more likely to be comprised of growth firms. If individuals surrounded by growth stocks are more apt to own non-dividend paying growth stocks themselves, there will be a negative correlation between the return of local firms and dividend ownership of individuals in the community. ${ }^{14}$

The share of firm value in the community comprised of technology companies is negatively correlated with stock market participation. There are at least two plausible explanations for this negative relation. First, if stock market investors in such areas own primarily technology stocks, the regressions may simply be picking up the fact that these technology firms over the sample period are less likely to pay dividends. In addition, because

\footnotetext{
${ }^{14}$ Data on stock returns of growth and value stocks was obtained from Ken French's web site (http://mba.tuck.dartmouth.edu/pages/faculty/ken.french/data_library.html) plus authors' calculations.
} 
capital gains are recorded only upon sale, our proxies may accurately capture equity ownership in the technology sector only if the individual sells stock over the period. Second, many of the individuals in this area may be employees of these technology companies, which suggests that part of their compensation package may come in the form of stock option grants. If an individual has a large portion of their compensation tied up in stock options, they may rationally choose to keep the rest of their portfolio in safer (i.e., non-equity) investments. Prior research [Heath, Huddart, and Lang 1999] suggests that most people, upon exercising their employee stock options, immediately sell the underlying stock, and, as a result, these proceeds would show up as ordinary income. We will address the issue of company stock ownership more generally in later specification checks.

\section{Results over Time}

Table 6 explores how the relations hold up over time. The community ownership variable and the share of firms within 50 miles coefficients are reliably significant in all years, including years of economic downturns (early 1990s) as well as years of rapid economic growth. There does appear to be a decline in the importance of community effects beginning in 1995, with the coefficient falling by about one-third. One possible explanation is that, to the extent that community effects arise from the exchange of information, the rise of the internet and/or the explosion in financial market news sources (e.g., CNBC) in the mid-1990s could have served as a substitute for word-of-mouth learning.

\section{Ruling Out an Alternative Hypothesis: Is It Just Owning Company Stock?}

Thus far, we have presented very robust estimates of a strong relation between an individual's equity participation propensity, the equity market participation rate of the 
individual's community, and the presence of local firms. However, a potential criticism of these basic results is that they could be driven by the role of company stock. Many companies encourage employees to purchase company stock, even subsidizing the offering through employee stock purchase plans. It is possible that our findings are at least partially contaminated by the tendency that "local" firms encourage employees to buy company stock, and that this is confounding our estimates of both the community effects (e.g., individual $i$ 's neighbors all work for the same company) and firm locality effects (the local firm is the firm at which individual $i$ works).

Our data allow us to test this alternative hypothesis directly in two ways. The first test, presented in column (1) of Table 7, provides results for the sub-sample of the population that is self-employed, ${ }^{15}$ a group that, by definition, will not be affected by the company-stock explanation. Using the combined dividend/capital gains proxy for stock ownership, we find that the effect of equity ownership in the community is still both statistically and economically significant. It suggests that a 10-percentage point increase in equity ownership in a community increases a self-employed individual's probability of stock ownership by 1.1 percentage points. This effect is about two-thirds of what it was in Table 5, suggesting that, at most, the company stock explanation accounts for one-third of the correlation. The local firm effects are also significant, and, in fact, are larger among the self-employed than the population as a whole. Assuming the self-employed are more financially sophisticated than the general population, then the local firm result could reflect that more financially savvy people are better able to collect value-relevant information about local firms, and thus are more apt to act upon this information

\footnotetext{
${ }^{15}$ Our definition of self-employed is that they report schedule $\mathrm{C}$ income (positive or negative) and have income from an employer of less than $\$ 10,000$.
} 
(i.e., buy stock of any good local firm(s) they discover). Indeed, the larger the share of firms local to the household, the more likely it is that there will be a local firm worth investing into.

A second test of the company stock hypothesis is to limit the sample to the approximately 10 percent of our sample that has no firms within 50 miles. Again, we see that there is still a significant correlation between individual and community equity market participation. Naturally, the local firm effects are not identified for this sample. These two sets of results together clearly suggest that our results are not attributable solely to a company stock phenomenon.

\section{E. Differential Effects by Degree of Financial Sophistication}

The first result we report in this study is that an individual's decision whether to invest in the stock market is influenced by the participation decision of others in the household's community (see Section 4.1). It is reasonable to hypothesize that this effect might be weaker among more financially sophisticated individuals. In short, we might expect that those familiar with basic principles of finance already understand the risks and rewards of equity market participation, and therefore make a decision to participate independently of what their peers do. Alternatively, those with very little exposure to finance may be much more influenced by what their co-workers and neighbors do. The extent to which this is true probably depends on the underlying cause of the community effect. For example, it is quite possible that conformity or external habit influences could be equally strong for financially savvy and less financially savvy households, whereas the provision of information about how to invest may be stronger among less financially savvy households.

Our second result is that equity market participation is influenced by the presence of local

firms. Whether this effect should vary by financial sophistication is ambiguous. If the presence 
of more local firms means that there is more information flowing about these firms, which in turn individual investors seem to have been able to use to generate returns superior to returns from investments into non-local firms [Ivković and Weisbenner, 2003], then one might expect that more financially sophisticated individuals would be more influenced by this factor. In other words, as the number of local firms increases, there is a greater chance a financially savvy individual, able to collect value-relevant information about stocks, will find a local firm in which it is worth investing. ${ }^{16}$ On the other hand, if the local firm effects do not provide profitable value-relevant information, but only serves to increase familiarity with the stock market, then one might expect the effect to be declining with financial sophistication.

Because we cannot directly observe financial sophistication, we proxy for it by examining how our effects differ across income groups, the implicit assumption being that higher income individuals, on average, are more financially sophisticated. The top panel of Table 8 shows that the effect of community ownership is indeed much stronger for lower income households. While this effect is statistically significant for all income groups, the community ownership effect among those earning less than $\$ 150,000$ per year is about three times stronger than the effect among those earning $\$ 150,000$ or more. The results also suggest that the local firm effect is strongest for high-income individuals, a finding consistent with the notion that a higher concentration of local firms provides information that can be utilized most effectively by higher income individuals. ${ }^{17}$

Arguably a better proxy for financial sophistication might be education. While our tax data does not allow us to observe the educational attainment of the taxpayer, we do know the

\footnotetext{
${ }^{16}$ Ivković and Weisbenner (2003) report that roughly one in five households invest in only local stocks, suggesting that the presence of local firms may effect not only the household portfolio composition, but also whether the household owns equity.

${ }^{17}$ In results not presented here, we confirm that the finding that the local firm effect is strongest for high income individual holds true even when the high-income sample is restricted to the self-employed.
} 
distribution of educational attainment in the household's zip code. The bottom panel of Table 8 divides the sample into thirds by the share of households in the zip code that have a college education, where college education is defined as obtaining a bachelor or graduate degree. We find a pattern similar to that of income, namely that the community ownership effect is somewhat stronger in less financially sophisticated areas, while the local firm effect is somewhat stronger in more financially sophisticated areas. Relative to income, the effect is less pronounced, which is to be expected given that our education measure is a zip-code-level, rather than an individual-level variable.

\section{F. Household Fixed Effects}

Up to this point, the results have rested upon the critical assumption that individual and zip-code-level controls are sufficient to control for different individual propensities to invest in stocks. However, an individual's location is not randomly assigned. As such, if individuals differ according to some unobservable characteristic Z (e.g., risk aversion, financial sophistication, etc.) and if individuals with similar values of $Z$ tend to live together, then our community ownership effect may simply be picking up the effect of this omitted $\mathrm{Z}$ variable.

Given the rich panel structure of our data, we are able to control for household fixed effects in our regressions. The inclusion of fixed effects means that we are identifying our relations of interest solely off of differences over time. As such, any fixed differences across individuals, be they observable (e.g., race or gender) or unobservable (e.g., risk aversion), will be differenced out of the results.

In addition to differencing out individual fixed effects, we continue to control for all the variables from Table 4 that vary over time. Thus, for our community effect, we are identifying 
solely off of differences in own equity market participation, and differences in community equity market participation, that are orthogonal to differences in all other controls. Where does any such variation come from? The most significant source of variation will come from individuals who change residences during the sample period; other variation comes from changes within a given community over time. Thus, one interpretation of these results is what happens to an individual's equity market participation if the individual moves to an area with a different community participation rate.

Results are shown in Table 9. In the full sample (panel A), the effect of community equity ownership is statistically significant and is largely unaffected by the inclusion of firm controls, demographic controls, and zip code controls. Interestingly, when the fixed-effects regressions are ran separately by income group, we find that the effect is concentrated among the individuals earning between $\$ 50,000$ and $\$ 150,000$ over the entire sample period. Indeed, within this income group, the magnitude of the community ownership effect is comparable to what we initially found in Table 5, that is, a 10 percentage point difference in community equity ownership leads to a 2 percentage point difference in the probability of owning stocks. It is not surprising that there is no relation between community equity ownership and an individual's own stock ownership in the high-income sub-sample, given our earlier cross-sectional results. One reason that the community effect is stronger in the middle-income group relative to the lowincome group in the fixed-effects framework is that there is more variation in the covariates of interest within this group. For example, comparing points in the distribution of differences in the maximum and minimum equity ownership in an individual's community over the sample period, 
we find larger differences for the middle income group, suggesting more of the middle income individuals are moving, allowing the community effect to be more easily identified. ${ }^{18}$

Given earlier results in the pooled cross-sections, it is not surprising that changes in the share of firms local to a high-income individual is associated with an increase in the high-income individual's propensity to own stock. The estimated effect from the fixed-effect regression suggests a five percentage point increase in the share of U. S. firms local to the individual boosts the likelihood of stock ownership by a high-income individual by 1.2 percentage points, a figure comparable to results obtained in the cross-sectional analysis.

In Panel B of table 9, we re-run our fixed effects specification focusing on a sample that consists entirely of movers. Specifically, we define a taxpayer as a mover if they spend at least two years in the same zip code, then move to another zip code that is at least 100 miles away, and remain there for at least two years after the year of the move. The 100-mile distance was chosen so that there is no overlap between the old and new community definitions. ${ }^{19}$ In the three columns, we report results for the full sample, still using fixed effects. The magnitude of the coefficients are nearly identical to the full sample results, although the standard errors go up substantially because our mover sample is only $4 \%$ of the total population. In the remaining columns, we repeat our break-down of the sample by income group, and find patterns quite similar to the full sample fixed effects results, namely, that the effect is concentrated among those households in the middle income group. Thus, when a middle income individual moves from one community to another, a 10 percentage point increase in the fraction of the community

\footnotetext{
${ }^{18}$ For example, the difference in the maximum and minimum equity ownership of an individual's community over the sample is less than five percentage points for one quarter of the individuals in the low-income group. By contrast, only one tenth of the individuals in the middle-income group has such a small difference in their community's equity ownership over the sample.

${ }^{19}$ Based on this definition, we have a sample of 4382 movers. Because we observe these individuals, on average, for 7-8 years, we have over 32,000 mover-year observations. Conditional on moving more than 100 miles, the mean distance of the move is 848 miles and the median is 713 miles.
} 
that owns equities leads to a 5 percentage point increase in the probability that the mover will subsequently enter the equity market. Importantly, this effect is strongest when we control for changes in demographic characteristics, such as income, providing support that the mover effect is not being driven off of large changes in income that are concurrent with the move. ${ }^{20}$

\section{G. Refining the Community Ownership Hypothesis - Peer Groups Matter}

Obviously, not all individuals in a 50-mile radius community associate with one another. Individuals tend to associate more frequently with other individuals of similar income, age, or other characteristics. As such, if our community ownership variable is really picking up peer effects, then we ought to find that people are more influenced by similar individuals than by less similar individuals.

To investigate this, we assign each observation in our sample to one of nine groups based on income and age. We then run a regression that allows us to test for within group and acrossgroup community effects. Specifically, we are interested in whether the equity market participation rate of "middle income, middle aged" individuals in a community has a larger effect on other "middle income, middle aged" individuals in the community than it does on other income and age groups in the same community. ${ }^{21}$

Table 10 reports the results. For 7 of the 9 groups, the "own group" community ownership effect is larger than the "cross-group" community ownership effect, and the results are statistically significant for 6 of these 7 groupings. The bottom row of Table 10 reports a

\footnotetext{
${ }^{20}$ In additional results not shown, we confirm that this finding is not being driven solely off of large income changes by further limiting the sample to movers for whom the difference between their maximum and minimum income over the period implied an annual change of less than 8 percent. The neighborhood effect is slightly larger and still statistically significant.

${ }^{21}$ Duflo and Saez (2003) used a similar identification strategy to identify peer effects in retirement plan participation.
} 
weighted average difference between "own group" effects and "cross group" effects of 6.8 percentage points. This suggests that a 20 percentage point increase in equity market participation by a particular age/income group in a community will raise the likelihood of equity ownership of a household in this group by 1.36 percentage points more than the equity ownership likelihood of a household from a different age/income group. The difference is highly significant. These results are very consistent with our overall interpretation that individuals are influenced to participate in the stock market by the actions of their peers.

\section{Conclusions}

This paper is the first to provide evidence regarding the role of two geographic effects that influence equity market participation. The first geographic effect is that individuals are influenced by the investment behavior of members of their community. This is true after controlling for a wide range of individual and zip-code-level financial and demographic characteristics, using instrumental variables, restricting the sample to self-employed individuals and to individuals with no publicly-traded firms in their community, and controlling for individual fixed effects. We also provide evidence that this effect is strongest for the least financially sophisticated households. Finally, we also show that the influence of community ownership is strongest within age and income groups. In other words, the equity market participation rate of individuals in the same income and age category has a stronger effect on an individual's own stock market participation relative to the participation rate of households belonging to other age and income groups. This is consistent with the hypothesis that "peers matter." 
The second geographic effect is that proximity to publicly-traded firms also increases equity market participation rates. In particular, the presence of publicly-traded firms within 50 miles and the share of U.S. market value located within the community are positively correlated with equity ownership of individuals. In contrast to the community ownership effects, the local firm effects appear to be stronger among higher income individuals. This result is consistent with a hypothesis that proximity to local firms may provide a pool of potentially profitable investments that is easier for more financially sophisticated individuals to discover, which in turn influences their decision to own stock. 


\section{References}

Abel. Andrew B., 2001. "The Effects of Investing Social Security Funds in the Stock Market When Fixed Costs Prevent Some Households from Holding Stocks," American Economic Review v91, n1 (March): 128-48.

Aizcorbe, Ana, Arthur Kennickell, and Kevin Moore (2003) "Recent Changes in U.S. Family Finances: Evidence from the 1998 and 2001 Survey of Consumer Finances", Federal Reserve Bulletin, vol. 89 (January 2003), pp. 1-32.

Amromin, Gene and Paul Smith, 2003. "What Explains Early Withdrawals from Retirement Accounts? Evidence from a Panel of Taxpayers," National Tax Journal v56, n3 (September): 595-612.

Banerjee, A., 1992, “A simple model of herd behavior," Quarterly Journal of Economics 107, 797-817.

Benartzi, Shlomo, 2001, Excessive extrapolation and the allocation of 401(k) accounts to company stock, Journal of Finance 56, 1747-64.

Bernheim, B. Douglas, “A Theory of Conformity” Journal of Political Economy v102, n5 (October 1994): 841-77.

Bertaut, Carol and Martha Starr-McCluer, "Household Portfolios in the United States," Finance and Economics Discussion Series, 2000-26, Board of Governors of the Federal Reserve System.

Bertrand, M., Luttmer, E. and Mullainathan, S., 2000, "Network effects and welfare cultures," Quarterly Journal of Economics 115, 1019-1055.

Brav, Alon; Constantinides, George M.; Geczy, Christopher C. “Asset Pricing with Heterogeneous Consumers and Limited Participation: Empirical Evidence" Journal of Political Economy v110, n4 (August 2002): 793-824.

Campbell, John Y.; Cochrane, John H. "By Force of Habit: A Consumption-Based Explanation of Aggregate Stock Market Behavior” Journal of Political Economy v107, n2 (April 1999): 20551 .

Case, A. and Katz, L., 1991, “The Company You Keep: The Effect of Family and Neighborhood on Disadvantaged Youths," NBER working paper 3705, May.

Coval, Joshua D.; Moskowitz, Tobias J. "The Geography of Investment: Informed Trading and Asset Prices" Journal of Political Economy v109, n4 (August 2001): 811-41.

Coval, Joshua D.; Moskowitz, Tobias J. "Home Bias at Home: Local Equity Preference in Domestic Portfolios “Journal of Finance v54, n6 (December 1999): 2045-73. 
DeMarzo, Peter M., Ron Kaniel and Ilan Kremer, 2002, "Diversification as a Public Good: Community Effects in Portfolio Choice," Stanford University working paper.

Diamond, Peter; John Geanakoplos, 2003, "Social Security Investment in Equities" The American Economic Review v93, n4, (September 2003): 1047 - 1974.

Duflo, Esther; Saez, Emmanuel, "The Role of Information and Social Interactions in Retirement Plan Decisions: Evidence from a Randomized Experiment" Quarterly Journal of Economics v118, n3 (August 2003): 815-42.

Duflo, Esther; Saez, Emmanuel, "Participation and Investment Decisions in a Retirement Plan: The Influence of Colleagues' Choices" Journal of Public Economics v85, n1 (July 2002): 12148 .

Ellison, G. and Fudenberg, D., 1993, "Rules of thumb for social learning," Journal of Political Economy 101, 93-126.

Ellison, G. and Fudenberg, D., 1995, "Word of mouth communication and social learning," Quarterly Journal of Economics 110, 93-125.

Fama, Eugene F.; French, Kenneth R. "The Equity Premium.” The Journal of Finance v57, n2 (April 2002): 637-59.

French, Kenneth R.; Poterba, James M. "Investor Diversification and International Equity Markets" American Economic Review v81, n2 (May 1991): 222-26.

Friedman, Joel and Robert Greenstein, "Exempting Corporate Dividends from Individual Income Taxes," Report from the Center for Budget and Policy Priorities, January 23, 2003.

Glaeser, E. L., Sacerdote, B., and Scheinkman, J., 1996, "Crime and social interactions," Quarterly Journal of Economics CXIV, 502-548.

Grinblatt, M. and Keloharju, M., 2000, "The investment behavior and performance of various investor-types: A study of Finland's unique data set," Journal of Financial Economics 55, 43-67.

Heath, Chip, Steven Huddart, and Mark Lang, 1999, "Psychological Factors and Stock Option Exercise," Quarterly Journal of Economics, 114, 601-627.

Heaton, John; Lucas, Deborah, "Stock Prices and Fundamentals," NBER Macroeconomics Annual 1999 (Volume 14): Cambridge and London: MIT Press, 2000: 213-42.

Hong, Harrison; Kubik, Jeffrey D.; Stein, Jeremy C., 2004, "Social Interaction and Stock-Market Participation," Journal of Finance, forthcoming.

Hubbard, R. Glenn; Skinner, Jonathan; Zeldes, Stephen P. "Precautionary Saving and Social Insurance " Journal of Political Economy v103, n2 (April 1995): 360-99. 
Huberman, Gur, "Familiarity Breeds Investment," Review of Financial Studies v14, n3 (Fall 2001): 659-80.

Ivković, Zoran, and Scott Weisbenner, (2003), "Local Does as Local Is: Information Content of the Geography of Individual Investors' Common Stock Investments,” Working Paper.

Liang, Nellie and Scott Weisbenner, "Investor Behavior and the Purchase of Company Stock in 401(k) Plans - The Importance of Plan Design," NBER Working Paper No. 9131, August 2002.

Mankiw, N. Gregory; Zeldes, Stephen P. “The Consumption of Stockholders and Nonstockholders" Journal of Financial Economics v29, n1 (March 1991): 97-112.

Mas-Colell, Andreu, Michael D. Whinston and Gerry R. Green, Microeconomic Theory, Oxford University Press, 1995.

Mehra, Rajnish; Prescott, Edward C., "The Equity Premium: A Puzzle," Journal of Monetary Economics v15, n2 (March 1985): 145-61.

Mitchell, Olivia S. and Stephen P. Utkus, "The Role of Company Stock in Defined Contribution Plans," NBER Working Paper 9250, October 2002.

Poterba, James M.; Samwick, Andrew, "Taxation and Household Portfolio Composition: U.S. Evidence from the 1980s and 1990s," NBER Working Paper: 7392 October 1999.

Scholz, John Karl, Ananth Seshadri and Surachai Khitatrakun, "Are Americans Saving Optimally for Retirement?” University of Wisconsin-Madison working paper, September 2003.

Shore, Stephen H. and Joshua White, "External Habit Formation and the Home Bias Puzzle," working paper, 2003.

Vissing-Jorgensen, Annette, "Limited Stock Market Participation and the Equity Premium Puzzle," University of Chicago working paper, 1999.

Zhu, Ning, "The Local Bias of Individual Investors," Yale ICF Working Paper No. 02-30, October 2002. 
Table 1

Correlation Between Actual Equity Ownership and Stock Ownership Proxies, Conditional on Filing Tax Return, Using Survey of Consumer Finances (SCF) 1989 - 1998

\begin{tabular}{|c|c|c|c|c|c|}
\hline Stock Ownership Proxies & 1989 & 1992 & 1995 & 1998 & $1989-1998$ \\
\hline Report Dividends & 0.66 & 0.65 & 0.63 & 0.57 & 0.62 \\
\hline Report Capital Gains & 0.44 & 0.46 & 0.47 & 0.49 & 0.47 \\
\hline $\begin{array}{l}\text { Report Dividends and/or } \\
\text { Capital Gains }\end{array}$ & 0.66 & 0.63 & 0.63 & 0.61 & 0.63 \\
\hline
\end{tabular}


Table 2

Equity Ownership Proxies (in percent), 1987 - 1996 Pooled $^{\mathrm{a}}$

\begin{tabular}{|c|c|c|c|c|}
\hline & $\begin{array}{c}\text { Equity Ownership } \\
\text { (SCF estimates) }\end{array}$ & $\begin{array}{c}\text { Report } \\
\text { Dividends and/or } \\
\text { Capital Gains }\end{array}$ & $\begin{array}{c}\text { Report } \\
\text { Dividends }\end{array}$ & $\begin{array}{c}\text { Report } \\
\text { Capital Gains }\end{array}$ \\
\hline Full Sample & $\begin{array}{c}22.1 \% \\
1989-98\end{array}$ & $29.6 \%$ & $25.6 \%$ & $17.9 \%$ \\
\hline \multicolumn{5}{|l|}{ By Year } \\
\hline 1987 & & 25.7 & 21.9 & 15.2 \\
\hline 1988 & & 27.1 & 23.2 & 14.7 \\
\hline 1989 & 19.0 & 28.1 & 24.2 & 15.8 \\
\hline 1990 & & 28.0 & 24.2 & 15.3 \\
\hline 1991 & & 28.6 & 24.7 & 16.2 \\
\hline 1992 & 20.0 & 30.1 & 26.1 & 18.2 \\
\hline 1993 & & 31.4 & 27.3 & 20.4 \\
\hline 1994 & & 32.5 & 28.2 & 21.0 \\
\hline 1995 & 21.5 & 33.2 & 28.9 & 21.9 \\
\hline 1996 & $\begin{array}{c}26.9 \\
\text { in } 1998 \\
\end{array}$ & 34.4 & 30.0 & 23.7 \\
\hline
\end{tabular}

${ }^{a}$ Notes: Sample is all individuals that file tax returns. Statistics are weighted by population weights. 
Table 3

Summary Statistics for Equity Ownership (in percent) and Presence of Local Firms, 1987-1996 Pooled ${ }^{\mathrm{a}}$

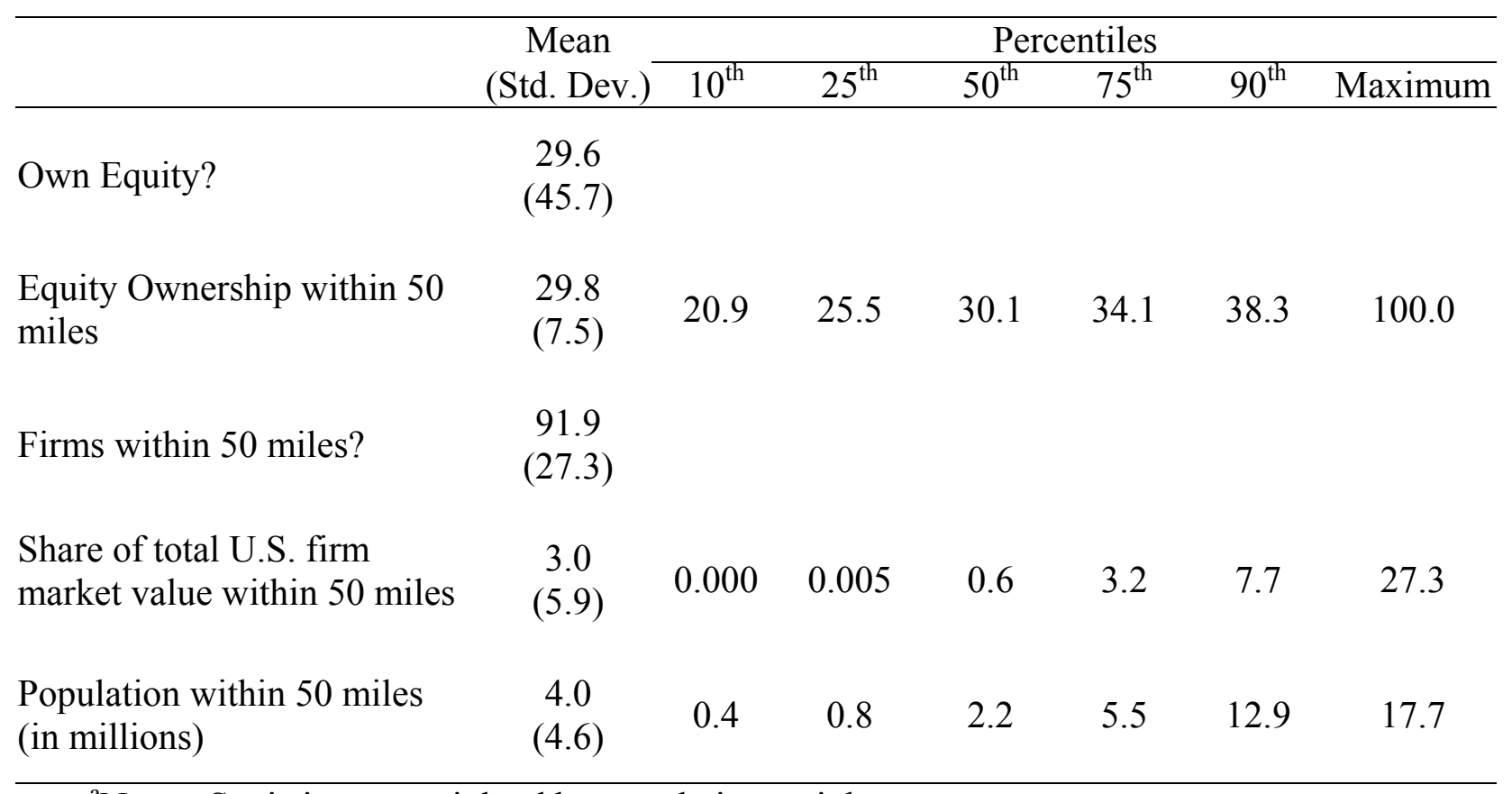

${ }^{\mathrm{a}}$ Notes: Statistics are weighted by population weights. 
Table 4

Regression of Stock Ownership (in percent), Focus on Income and Demographic Controls, 1987 - 1996

\begin{tabular}{|c|c|c|c|}
\hline $\begin{array}{l}\text { Income and Age Controls for Household } \\
\text { (Income } 0-50 \mathrm{~K} \text { and Age }<40 \text { omitted) }\end{array}$ & & $\begin{array}{l}\text { Race/Ethnicity across Household's } \\
\text { Zip Code (White omitted) }\end{array}$ & \\
\hline Income negative? & $-5.0 * * *$ & Black & $-3.5^{* * *}$ \\
\hline Maximum $(0$, Income $)$ in $\$ 000 \mathrm{~s}$ & $0.0002^{* * *}$ & Indian & -3.1 \\
\hline Maximum $(0$, Income $)$ squared & $-8 \mathrm{e}-10^{* * *}$ & Asian & $-7.8^{* * *}$ \\
\hline Income $50-150 \mathrm{~K}$ & $8.5^{* * *}$ & Other race & -4.0 \\
\hline Income $150 \mathrm{~K}+$ & $28.1^{* * *}$ & * Hispanic & $-6.0^{* * *}$ \\
\hline Age (in years) & $0.65^{* * *}$ & Mean house price in zip $(\$ 000 \mathrm{~s})$ & -0.002 \\
\hline Age squared & 0.0002 & $\begin{array}{l}\text { Occupation in Household's zip } \\
\text { (Executive / Manager omitted) }\end{array}$ & \\
\hline Age $40-64$ & $1.2^{* * *}$ & * Professional / Specialist & 1.6 \\
\hline Age $65+$ & $3.7^{* * *}$ & Technician & 11.9 \\
\hline $\begin{array}{l}\text { Filing Status/Deductions taken by HH } \\
\text { (Married omitted for Filing Status) }\end{array}$ & & Sales & 5.5 \\
\hline Claim mortgage & $5.8^{* * *}$ & Clerical & $-21.6^{* * *}$ \\
\hline Single filing status - male & $-4.5^{* * *}$ & Private & $-32.8^{* * *}$ \\
\hline Single filing status - female & $-3.9^{* * *}$ & Protective & 4.8 \\
\hline Head of Household - male & $-9.4^{* * *}$ & Service & $7.2^{*}$ \\
\hline Head of Household - female & $-11.0^{* * *}$ & Farming & 4.8 \\
\hline Number of Dependents & $-0.27^{* * *}$ & Crafts & $-21.4^{* * *}$ \\
\hline Self-employed & $3.6^{* * *}$ & Operators & $-26.8^{* * *}$ \\
\hline Schedule E & $24.6^{* * *}$ & Transportation / Materials & $-43.3^{* * *}$ \\
\hline Alternative Minimum Tax & $8.1^{* * *}$ & Laborers & 12.0 \\
\hline DC Plan & $5.0^{* * *}$ & $\begin{array}{l}\text { Sector in household's zip } \\
\text { (For Profit omitted) }\end{array}$ & \\
\hline $\begin{array}{l}\text { Education across Household's Zip Code } \\
\left(1^{\text {st }}-8^{\text {th }} \text { Grade Education omitted }\right)\end{array}$ & & Not For Profit & $8.8^{* * *}$ \\
\hline Start high school & $-13.6^{* * *}$ & Local Government & $-9.6^{* *}$ \\
\hline Graduate high school & 3.7 & State Government & $-21.4^{* * *}$ \\
\hline Some college & -4.9 & Federal Government & $-21.1^{* * *}$ \\
\hline Associate degree & -2.6 & Self-Employed & -1.8 \\
\hline Bachelor degree & $18.5^{* * *}$ & Nonpaid & -3.4 \\
\hline Graduate degree & $8.2^{*}$ & \multicolumn{2}{|c|}{$\#$ of obs. $=753,103$} \\
\hline
\end{tabular}


Table 5

Regression of Stock Ownership (in percent, various proxies for stock ownership), 1987 - 1996 Pooled $^{\text {a }}$

\begin{tabular}{|c|c|c|c|c|c|c|c|c|c|}
\hline & \multicolumn{3}{|c|}{$\begin{array}{l}\text { Dividend income and/or } \\
\text { capital gains used as proxv }\end{array}$} & \multicolumn{3}{|c|}{ Dividend income used as proxy } & \multicolumn{3}{|c|}{ Capital gains used as proxy } \\
\hline & (1) & $(2)$ & (3) & (4) & $(5)$ & $(6)$ & $(7)$ & $(8)$ & (9) \\
\hline Equity Ownership within 50 miles & $\begin{array}{l}16.2^{* * *} \\
(1.5)^{2}\end{array}$ & $\begin{array}{l}15.1^{* * * *} \\
(1.5)^{2}\end{array}$ & $\begin{array}{l}15.7^{* * *} \\
(2.3)\end{array}$ & $\begin{array}{l}24.1{ }^{* * *} \\
(1.8)\end{array}$ & $\begin{array}{l}22.9^{* * *} \\
(1.8)\end{array}$ & $\begin{array}{l}25.8 \\
(2.8)\end{array}$ & $\begin{array}{l}20.6^{* * *} \\
(1.7)\end{array}$ & $\begin{array}{l}20.4^{* * *} \\
(1.7)\end{array}$ & $\begin{array}{l}28.1^{* * * *} \\
(2.7)\end{array}$ \\
\hline Firms within 50 miles? & $\begin{array}{l}1.17^{* * *} \\
(0.45)\end{array}$ & $\begin{array}{l}1.08^{* *} \\
(0.45)\end{array}$ & $\begin{array}{l}1.07^{* *} \\
(0.45)\end{array}$ & $\begin{array}{l}1.32^{* * *} \\
(0.50)\end{array}$ & $\begin{array}{l}1.21^{* *} \\
(0.50)\end{array}$ & $\begin{array}{l}1.14^{* *} \\
(0.50)\end{array}$ & $(0.41)$ & $\begin{array}{l}1.52^{* * *} \\
(0.41)\end{array}$ & $\begin{array}{l}1.47^{* * *} \\
(0.41)\end{array}$ \\
\hline $\begin{array}{l}\text { Share of total U.S. firm market } \\
\text { value within } 50 \text { miles }\end{array}$ & $\begin{array}{l}20.5^{* * *} \\
(3.5)\end{array}$ & $\begin{array}{l}20.0^{* * *} \\
(3.5)\end{array}$ & $\begin{array}{l}19.9^{* * *} \\
(3.5)\end{array}$ & $\begin{array}{l}33.7^{* * *} \\
(3.9)\end{array}$ & $\begin{array}{l}33.5^{* * *} \\
(3.9)\end{array}$ & $\begin{array}{l}33.2^{* * *} \\
(3.9)\end{array}$ & $\begin{array}{l}28.6^{* * *} \\
(3.2)\end{array}$ & $\begin{array}{l}28.0^{* * *} \\
(3.2)\end{array}$ & $\begin{array}{l}27.2^{* * *} \\
(3.3)\end{array}$ \\
\hline $\begin{array}{l}\text { Equally-weighted average return of } \\
\text { firms within } 50 \text { miles }\end{array}$ & $\begin{array}{r}-0.12 \\
(0.19)\end{array}$ & $\begin{array}{r}-0.15 \\
(0.19)\end{array}$ & $\begin{array}{l}-0.15 \\
(0.19)\end{array}$ & $\begin{array}{l}-0.37^{*} \\
(0.20)\end{array}$ & $\begin{array}{l}-0.40^{* *} \\
(0.20)\end{array}$ & $\begin{array}{l}-0.40^{* *} \\
(0.20)\end{array}$ & $\begin{array}{r}0.20 \\
(0.19)\end{array}$ & $\begin{array}{r}0.16 \\
(0.19)\end{array}$ & $\begin{array}{r}0.13 \\
(0.19)\end{array}$ \\
\hline $\begin{array}{l}\text { Share of firm value within } 50 \text { miles } \\
\text { in technology sector }\end{array}$ & $\begin{array}{l}-1.55^{* * *} \\
(0.62)\end{array}$ & $\begin{array}{l}-1.45^{* *} \\
(0.62)\end{array}$ & $\begin{array}{l}-1.46^{* *} \\
(0.62)\end{array}$ & $\begin{array}{l}-1.77^{* * *} \\
(0.68)\end{array}$ & $\begin{array}{l}-1.68^{* * *} \\
(0.67)\end{array}$ & $\begin{array}{l}-1.72^{* * *} \\
(0.67)\end{array}$ & $\begin{array}{l}-1.46^{* * *} \\
(0.56)\end{array}$ & $\begin{array}{l}-1.35^{* *} \\
(0.56)\end{array}$ & $\begin{array}{l}-1.52^{* * *} \\
(0.56)\end{array}$ \\
\hline $\begin{array}{l}\text { Firm employees* } 1,000 / \\
\text { total population within } 50 \text { miles }\end{array}$ & $\begin{array}{r}0.59 \\
(1.31)\end{array}$ & $\begin{array}{r}0.35 \\
(1.31)\end{array}$ & $\begin{array}{r}0.28 \\
(1.32)\end{array}$ & $\begin{array}{r}-0.07 \\
(1.43)\end{array}$ & $\begin{array}{r}-0.33 \\
(1.43)\end{array}$ & $\begin{array}{r}-0.66 \\
(1.45)\end{array}$ & $\begin{array}{l}-1.15 \\
(1.17)\end{array}$ & $\begin{array}{l}-1.54 \\
(1.17)\end{array}$ & $\begin{array}{l}-1.87 \\
(1.18)\end{array}$ \\
\hline Year dummy variables? & Yes & Yes & Yes & Yes & Yes & Yes & Yes & Yes & Yes \\
\hline Demographic controls? & Yes & Yes & Yes & Yes & Yes & Yes & Yes & Yes & Yes \\
\hline Zip code controls? & No & Yes & Yes & No & Yes & Yes & No & Yes & Yes \\
\hline IV for equity own within 50 miles? & No & No & Yes & No & No & Yes & No & No & Yes \\
\hline $\mathrm{R}^{2}$ & 0.417 & 0.418 & 0.418 & 0.353 & 0.353 & 0.353 & 0.440 & 0.441 & 0.441 \\
\hline Number of observations & 753,103 & 753,103 & 753,103 & 753,103 & 753,103 & 753,103 & 753,103 & 753,103 & 753,103 \\
\hline
\end{tabular}

${ }^{\mathrm{a}}$ Notes: Instruments for equity ownership of the area within 50-miles of the household include income controls, age controls, deductions taken (i.e., mortgage interest and number of dependents), filing status, income/forms filed (self-employed, Schedule E, Alternative Minimum Tax, defined contribution plan contributions), education, race/ethnicity, house price, and occupation and sector shares of the people within 50 miles of the household. Zip code controls include income controls, age controls, deductions taken (i.e., mortgage interest and number of dependents), income/forms filed (self-employed, Schedule E, Alternative Minimum Tax, defined contribution plan contributions), and filing status of the household's zip code.

${ }_{* * *}^{* * *},{ }^{*}$ Significance at the 1 percent, 5 percent, and 10 percent levels, respectively. 
Table 6

Regression of Stock Ownership (in Percent, Report Dividend Income and/or Capital Gains Used as Proxy), $1987-1996$ by Year $^{\mathrm{a}}$

\begin{tabular}{|c|c|c|c|c|c|c|c|c|c|c|}
\hline & 1987 & 1988 & 1989 & 1990 & 1991 & 1992 & 1993 & 1994 & 1995 & 1996 \\
\hline $\begin{array}{l}\text { Equity Ownership } \\
\text { within } 50 \text { miles }\end{array}$ & $\begin{array}{l}17.5^{* * *} \\
(2.5)\end{array}$ & $\begin{array}{l}16.7^{* * *} \\
(2.5)\end{array}$ & $\begin{array}{l}15.7^{* * *} \\
(2.6)\end{array}$ & $\begin{array}{l}20.1^{* * *} \\
(2.5)\end{array}$ & $\begin{array}{l}12.8^{* * *} \\
(2.5)\end{array}$ & $\begin{array}{l}12.6^{* * *} \\
(2.5)\end{array}$ & $\begin{array}{l}14.4^{* * *} \\
(2.5)\end{array}$ & $\begin{array}{l}15.5^{* * *} \\
(2.5)\end{array}$ & $\begin{array}{l}10.3^{* * *} \\
(2.4)\end{array}$ & $\begin{array}{l}9.5^{* * *} \\
(2.5)\end{array}$ \\
\hline Firms within 50 miles? & $\begin{array}{r}1.03^{*} \\
(0.62)\end{array}$ & $\begin{array}{r}-0.02 \\
(0.64)\end{array}$ & $\begin{array}{r}1.01 \\
(0.69)\end{array}$ & $\begin{array}{l}1.71^{* * *} \\
(0.69)\end{array}$ & $\begin{array}{r}1.10 \\
(0.71)\end{array}$ & $\begin{array}{r}0.76 \\
(0.73)\end{array}$ & $\begin{array}{l}1.45^{* *} \\
(0.70)\end{array}$ & $\begin{array}{r}0.55 \\
(0.72)\end{array}$ & $\begin{array}{r}1.09 \\
(0.75)\end{array}$ & $\begin{array}{l}1.47^{* *} \\
(0.78)\end{array}$ \\
\hline $\begin{array}{l}\text { Share of total U.S. firm } \\
\text { market value within } 50 \text { miles }\end{array}$ & $\begin{array}{l}15.1^{* * *} \\
(4.5)\end{array}$ & $\begin{array}{r}9.0^{*} \\
(4.8)\end{array}$ & $\begin{array}{l}17.2^{* * *} \\
(5.0)\end{array}$ & $\begin{array}{l}20.6^{* * *} \\
(4.8)\end{array}$ & $\begin{array}{l}22.9^{* * *} \\
(4.5)\end{array}$ & $\begin{array}{l}17.9^{* * *} \\
(4.7)\end{array}$ & $\begin{array}{l}23.1^{* * *} \\
(5.1)^{-}\end{array}$ & $\begin{array}{l}24.1^{* * *} \\
(5.5)^{-}\end{array}$ & $\begin{array}{l}25.4^{* * *} \\
(5.5)\end{array}$ & $\begin{array}{l}19.2^{* *} \\
(5.6)\end{array}$ \\
\hline Firm Controls? & Yes & Yes & Yes & Yes & Yes & Yes & Yes & Yes & Yes & Yes \\
\hline Demographic controls? & Yes & Yes & Yes & Yes & Yes & Yes & Yes & Yes & Yes & Yes \\
\hline Zip code controls? & Yes & Yes & Yes & Yes & Yes & Yes & Yes & Yes & Yes & Yes \\
\hline Adjusted $\mathrm{R}^{2}$ & 0.461 & 0.438 & 0.432 & 0.425 & 0.414 & 0.411 & 0.402 & 0.399 & 0.393 & 0.386 \\
\hline Number of observations & 84,228 & 80,969 & 79,104 & 77,493 & 75,702 & 74,000 & 72,509 & 71,119 & 70,072 & 67,907 \\
\hline
\end{tabular}

${ }^{a}$ Notes: Regressions include local firm controls, demographics controls, and zip-code-level demographic controls. See appendix for details. 
Table 7

Robustness Checks of Stock Ownership Results to Company Stock Effect

(in percent, report dividend income and/or capital gains used as proxy)

\begin{tabular}{|c|c|c|}
\hline & Self-Employed & $\begin{array}{l}\text { NO Publicly-Traded Firm } \\
\text { within } 50 \text { miles }\end{array}$ \\
\hline Equity Ownership within 50 miles & $\begin{array}{l}10.9^{* * *} \\
(3.3)\end{array}$ & $\begin{array}{c}8.8^{* * *} \\
(2.5)\end{array}$ \\
\hline Firms within 50 miles? & $\begin{array}{r}1.63^{*} \\
(0.99)\end{array}$ & \\
\hline Share of total U.S. firm value within 50 miles & $\begin{array}{l}35.1^{* * *} \\
(8.2)\end{array}$ & \\
\hline Adjusted $\mathrm{R}^{2}$ & 0.320 & 0.379 \\
\hline Number of observations & 102,518 & 47,977 \\
\hline
\end{tabular}

Regressions include local firm controls (excluded in no publicly-traded firm within 50 miles regression), demographic controls, and zip-code-level demographic controls.

${ }^{* * * *},{ }^{* *},{ }^{*}$ Significance at the 1 percent, 5 percent, and 10 percent levels, respectively. 
Table 8

Stock Ownership Regressions by Proxies for Financial Sophistication

(in percent, report dividend income and/or capital gains used as proxy)

\begin{tabular}{|c|c|c|c|}
\hline & \multicolumn{3}{|c|}{ Regression by Income Groups (in \$000s) } \\
\hline Equity Ownership within 50 miles & $\begin{array}{c}0-50 \\
21.3^{\text {*** }} \\
(2.2)\end{array}$ & $\begin{array}{c}50-150 \\
19.8^{* * *} \\
(3.4)\end{array}$ & $\begin{array}{l}\frac{150+}{6.6^{* * *}} \\
(1.8)\end{array}$ \\
\hline Firms within 50 miles? & $\begin{array}{r}0.43 \\
(0.61)\end{array}$ & $\begin{array}{r}1.25 \\
(0.98)\end{array}$ & $\begin{array}{l}1.47^{* * *} \\
(0.59)\end{array}$ \\
\hline Share of total U.S. firm value within 50 miles & $\begin{array}{r}8.5 \\
(6.2)\end{array}$ & $\begin{array}{l}16.5^{* *} \\
(7.9)\end{array}$ & $\begin{array}{l}32.6^{* * *} \\
(3.5)\end{array}$ \\
\hline $\begin{array}{l}\text { Adjusted } \mathrm{R}^{2} \\
\text { Number of observations }\end{array}$ & $\begin{array}{c}0.349 \\
276,188\end{array}$ & $\begin{array}{c}0.204 \\
194,482 \\
\end{array}$ & $\begin{array}{c}0.086 \\
282,433\end{array}$ \\
\hline
\end{tabular}

Regression by Percent of Individuals in

Taxpayer's Zip Code with College Education

\begin{tabular}{|c|c|c|c|}
\hline & College $<16.5 \%$ & $16.5 \%<$ College $>33.8 \%$ & College $>33.8 \%$ \\
\hline Equity Ownership within 50 miles & $\begin{array}{l}17.5^{* * *} \\
(2.2)\end{array}$ & $\begin{array}{l}12.7^{* * *} \\
(2.6)\end{array}$ & $\begin{array}{l}12.7^{* * *} \\
(3.6)\end{array}$ \\
\hline Firms within 50 miles? & $\begin{array}{r}0.94^{*} \\
(0.57)\end{array}$ & $\begin{array}{r}0.05 \\
(0.81)\end{array}$ & $\begin{array}{r}0.57 \\
(1.69)\end{array}$ \\
\hline Share of total U.S. firm value within 50 miles & $\begin{array}{r}8.8 \\
(8.0)\end{array}$ & $\begin{array}{l}25.5^{* * *} \\
(7.0)\end{array}$ & $\begin{array}{l}20.4^{* * *} \\
(5.1)\end{array}$ \\
\hline $\begin{array}{l}\text { Adjusted } \mathrm{R}^{2} \\
\text { Number of observations }\end{array}$ & $\begin{array}{c}0.383 \\
251,105\end{array}$ & $\begin{array}{c}0.371 \\
251,061\end{array}$ & $\begin{array}{c}0.316 \\
250,937\end{array}$ \\
\hline
\end{tabular}

Regressions include local firm controls, demographic controls, and zip-code-level demographic controls. College education is defined as having obtained a bachelor or graduate degree.

${ }^{* * *},{ }^{* *},{ }^{*}$ Significance at the 1 percent, 5 percent, and 10 percent levels, respectively. 
Table 9

Regression of Stock Ownership with Household Fixed Effects, 1987 - 1996 pooled $^{\mathrm{a}}$

\begin{tabular}{|c|c|c|c|c|c|c|c|c|c|}
\hline \multicolumn{10}{|c|}{ Panel A: Full Sample } \\
\hline & \multicolumn{3}{|c|}{ Full Sample } & \multicolumn{2}{|c|}{$\begin{array}{l}\text { Income } \$ 0-50 \mathrm{~K} \\
\text { throughout sample }\end{array}$} & \multicolumn{2}{|c|}{$\begin{array}{c}\text { Income } \$ 50-150 \mathrm{~K} \\
\text { throughout sample }\end{array}$} & \multicolumn{2}{|c|}{$\begin{array}{c}\text { Income } \$ 150 \mathrm{~K}+ \\
\text { throughout sample }\end{array}$} \\
\hline & (1) & $(2)$ & (3) & (4) & (5) & (6) & (7) & (8) & (9) \\
\hline Equity Ownership within 50 miles & $\begin{array}{l}3.3^{* * *} \\
(1.2)\end{array}$ & $3.3^{* * * *}$ & $\begin{array}{l}3.7^{* * *} \\
(1.2)\end{array}$ & $\begin{array}{r}1.5 \\
(2.0)\end{array}$ & $\begin{array}{r}1.6 \\
(2.0)\end{array}$ & $\begin{array}{l}20.1 \\
(5.1)\end{array}$ & $\begin{array}{l}19.0 \\
(2.9)\end{array}$ & $\begin{array}{r}0.5 \\
(2.2)\end{array}$ & $\begin{array}{r}1.0 \\
(2.3)\end{array}$ \\
\hline Firms within 50 miles? & & $\begin{array}{r}0.27 \\
(0.37)\end{array}$ & $\begin{array}{r}0.20 \\
(0.38)\end{array}$ & & $\begin{array}{r}-0.61 \\
(0.56)\end{array}$ & & $\begin{array}{r}0.60 \\
(1.70)\end{array}$ & & $\begin{array}{r}0.94 \\
(0.79)\end{array}$ \\
\hline $\begin{array}{l}\text { Share of total U.S. firm market } \\
\text { value within } 50 \text { miles }\end{array}$ & & $\begin{array}{r}0.4 \\
(4.8)\end{array}$ & $\begin{array}{r}1.3 \\
(4.9)\end{array}$ & & $\begin{array}{r}-16.2 \\
(10.5)\end{array}$ & & $\begin{array}{l}-24.0 \\
(28.7)\end{array}$ & & $\begin{array}{l}24.8^{* * *} \\
(7.3)\end{array}$ \\
\hline Year dummy variables? & Yes & Yes & Yes & Yes & Yes & Yes & Yes & Yes & Yes \\
\hline Firm controls? & No & Yes & Yes & No & Yes & No & Yes & No & Yes \\
\hline Demographic controls? & No & No & Yes & No & Yes & No & Yes & No & Yes \\
\hline Zip code controls? & No & No & Yes & No & Yes & No & Yes & No & Yes \\
\hline $\mathrm{R}^{2}$ & 0.759 & 0.759 & 0.762 & 0.766 & 0.766 & 0.615 & 0.618 & 0.472 & 0.475 \\
\hline Number of observations & 753,253 & 753,253 & 753,103 & 157,894 & 157,811 & 72,076 & 72,074 & 168,314 & 168,301 \\
\hline
\end{tabular}

a Notes: ${ }^{* * *},{ }^{* *},{ }^{*}$ Significance at the 1 percent, 5 percent, and 10 percent levels, respectively. 
Table 9: Continued

Regression of Stock Ownership with Household Fixed Effects, 1987 - 1996 pooled $^{\mathrm{a}}$

Panel B: Households that move by at least 100 miles (exclude year of move)

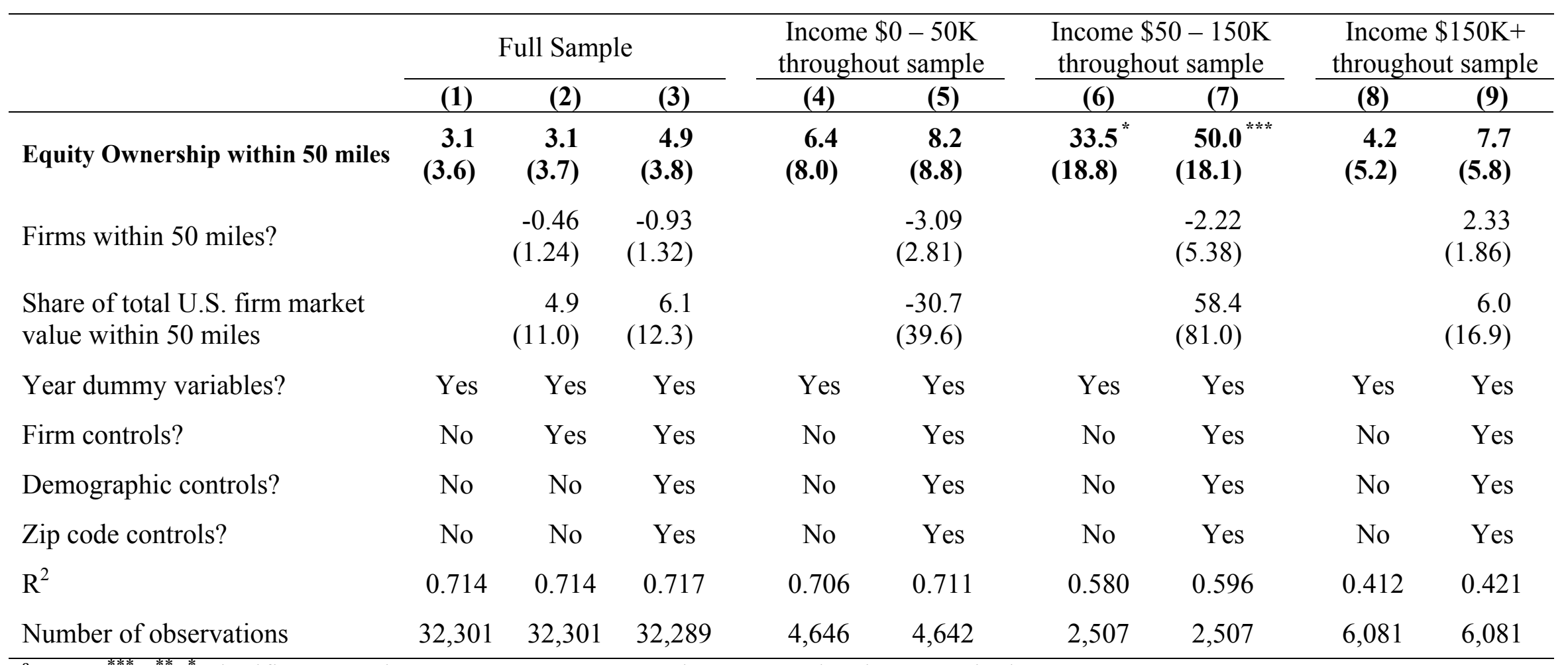

a Notes: ${ }^{* * *},{ }^{* *},{ }^{*}$ Significance at the 1 percent, 5 percent, and 10 percent levels, respectively. 
Table 10

Importance of Equity Ownership of Households in Same Age-Income Group

\begin{tabular}{|c|c|c|c|}
\hline Age-Income Group & $\begin{array}{l}\text { Effect of Average Equity } \\
\text { Ownership of this Group Upon } \\
\text { Individuals in THIS Group }\end{array}$ & $\begin{array}{c}\text { Effect of Average Equity } \\
\text { Ownership of this Group Upon } \\
\text { Individuals in OTHER Groups }\end{array}$ & Difference \\
\hline Age $<40$, Income $0-50 \mathrm{~K}$ & $\begin{array}{r}-0.0 \\
(3.3)\end{array}$ & $\begin{array}{r}2.6 \\
(1.8)\end{array}$ & $\begin{array}{l}-2.7 \\
(3.6)\end{array}$ \\
\hline Age $<40$, Income $50-150 \mathrm{~K}$ & $\begin{array}{l}6.5^{* * *} \\
(2.4)\end{array}$ & $\begin{array}{l}2.7^{* * *} \\
(0.7)\end{array}$ & $\begin{array}{r}3.8 \\
(2.4)\end{array}$ \\
\hline Age $<40$, Income $150 \mathrm{~K}+$ & $\begin{array}{l}14.7^{* * *} \\
(1.0)\end{array}$ & $\begin{array}{r}0.4 \\
(0.3)\end{array}$ & $\begin{array}{l}14.3^{* * *} \\
(1.0)\end{array}$ \\
\hline $40 \leq$ Age $<65$, Income $0-50 \mathrm{~K}$ & $\begin{array}{l}16.3^{* * *} \\
(2.7)\end{array}$ & $\begin{array}{l}3.3^{* * *} \\
(1.2)\end{array}$ & $\begin{array}{l}13.0^{* * *} \\
(2.7)\end{array}$ \\
\hline $40 \leq$ Age $<65$, Income $50-150 \mathrm{~K}$ & $\begin{array}{l}5.5^{* * *} \\
(2.1)\end{array}$ & $\begin{array}{c}1.6^{*} \\
(1.0)\end{array}$ & $\begin{array}{l}3.9^{* *} \\
(2.0)\end{array}$ \\
\hline $40 \leq$ Age $<65$, Income $150 \mathrm{~K}+$ & $\begin{array}{l}4.4^{* * *} \\
(0.7)\end{array}$ & $\begin{array}{c}1.0^{*} \\
(0.5)\end{array}$ & $\begin{array}{l}3.4^{* * *} \\
(0.8)\end{array}$ \\
\hline Age $\geq 65$, Income $0-50 \mathrm{~K}$ & $\begin{array}{l}33.0^{* * *} \\
(1.8)\end{array}$ & $\begin{array}{r}0.7 \\
(0.8)\end{array}$ & $\begin{array}{l}32.3^{* * *} \\
(1.6)\end{array}$ \\
\hline Age $\geq 65$, Income $50-150 \mathrm{~K}$ & $\begin{array}{l}16.3^{* * *} \\
(1.3)^{2}\end{array}$ & $\begin{array}{l}-0.5^{*} \\
(0.3)\end{array}$ & $\begin{array}{l}16.8^{* * *} \\
(1.3)^{2}\end{array}$ \\
\hline Age $\geq 65$, Income $150 \mathrm{~K}+$ & $\begin{array}{l}-5.0^{* * *} \\
(0.7)\end{array}$ & $\begin{array}{r}0.4 \\
(0.3)\end{array}$ & $\begin{array}{l}-5.4^{* * *} \\
(0.8)\end{array}$ \\
\hline Average Effect Across Households & $\begin{array}{l}8.4^{* * *} \\
(0.9)\end{array}$ & $\begin{array}{l}1.6^{* * *} \\
(0.3)\end{array}$ & $\begin{array}{l}6.8^{* * *} \\
(0.9)\end{array}$ \\
\hline Adjusted $\mathrm{R}^{2}=0.429$ & \multicolumn{3}{|c|}{ Number of Observations $=680,317$} \\
\hline
\end{tabular}

Regressions also include local firm controls, demographic controls, and zip-code-level demographic controls.

${ }^{* * *},{ }^{* *},{ }^{*}$ Significance at the 1 percent, 5 percent, and 10 percent levels, respectively. 


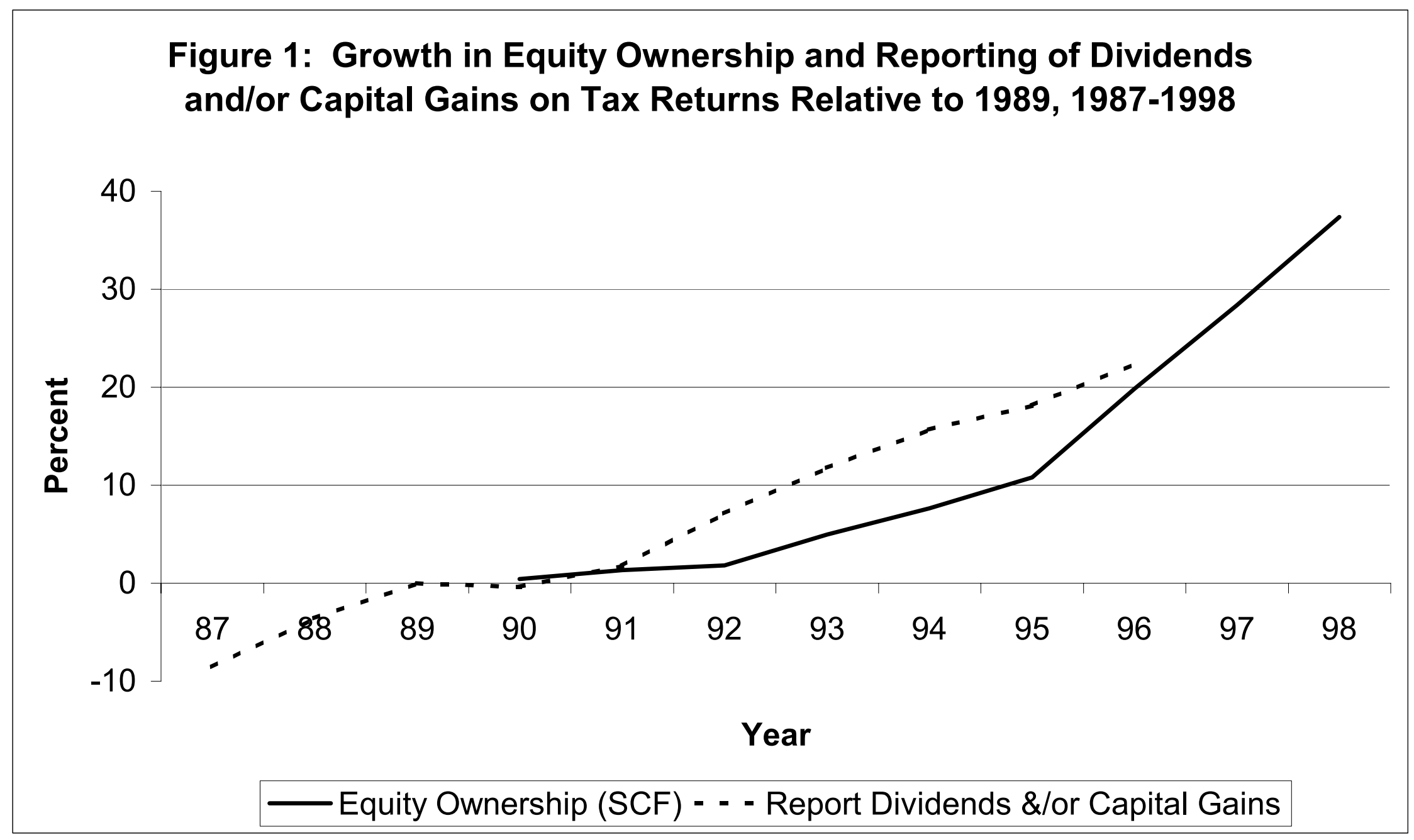

Equity ownership estimates are provided by the SCF for 1989, 1992, 1995, and 1998. Equity ownership estimates for years between surveys are obtained by a linear interpolation. 


\section{Appendix Table 1: Regression of Stock Ownership (in percent), Focus on Income and Demographic Controls, 1987 - 1996}

\begin{tabular}{|c|c|c|c|c|c|}
\hline $\begin{array}{l}\text { Income and Age Controls for Household } \\
\text { (Income } 0-50 \mathrm{~K} \text { and Age }<40 \text { omitted) }\end{array}$ & & Associate degree & -6.2 & State Government & $-20.0^{* * *}$ \\
\hline Income negative? & $-5.1^{* * *}$ & Bachelor degree & $12.6^{* * *}$ & Federal Government & $-18.1^{* * *}$ \\
\hline Maximum $(0$, Income $)$ in $\$ 000 \mathrm{~s}$ & $0.0002^{* * *}$ & Graduate degree & 0.9 & Self-Employed & 0.6 \\
\hline Maximum $(0$, Income $)$ squared & $-7 \mathrm{e}-10^{* * *}$ & $\begin{array}{l}\text { Race/Ethnicity across Household's } \\
\text { Zip Code (White omitted) }\end{array}$ & & Nonpaid & -7.1 \\
\hline Income $50-150 \mathrm{~K}$ & $8.1^{* * *}$ & Black / Indian & $-2.5^{* * *}$ & $\begin{array}{l}\text { Income and Age Controls for HH's ZIP CODE } \\
\text { (Income } 0-50 \mathrm{~K} \text { and Age <40 omitted) }\end{array}$ & \\
\hline Income $150 \mathrm{~K}+$ & $27.3^{* * *}$ & Asian & $-6.5^{* * *}$ & Average zip code income negative? & 0.8 \\
\hline Age (in years) & $0.69^{* * *}$ & Other Race & -0.6 & Maximum (0, Average Income) in $\$ 000 \mathrm{~s}$ & $0.0013^{* * *}$ \\
\hline Age squared & -0.0002 & Hispanic & $-4.9^{* * *}$ & Maximum ( 0 , Average Income) squared & $-2 \mathrm{e}-08^{* * *}$ \\
\hline Age $40-64$ & $1.5^{* * *}$ & Average House Price in zip (\$000s) & 0.001 & Income $50-150 \mathrm{~K}$ (share for zip code) & $0.9^{* * *}$ \\
\hline Age $65+$ & $3.2^{* * *}$ & $\begin{array}{l}\text { Occupation in HH's Zip } \\
\text { (Executive / Manager omitted) }\end{array}$ & & Income $150 \mathrm{~K}+$ (share for zip code $)$ & $2.9^{* * *}$ \\
\hline $\begin{array}{l}\text { Filing Status and Deductions taken by } \\
\text { Household (Married omitted for Filing Status) }\end{array}$ & & Professional / Specialist & $9.2^{* *}$ & Average Age (for zip code, in years) & $-0.17^{* * *}$ \\
\hline Claim mortgage & $5.2^{* * *}$ & Technician & $13.4^{*}$ & Average Age (for zip code) squared & $0.0017^{* * *}$ \\
\hline Single filing status - male & $-4.5^{* * *}$ & Sales & 7.2 & Age $40-64$ (share for zip code) & $-1.3^{* * *}$ \\
\hline Single filing status - female & $-4.3^{* * *}$ & Clerical & $-17.8^{* * *}$ & Age $65+$ (share for zip code) & $1.6^{* *}$ \\
\hline Head of Household filing status - male & $-9.5^{* * *}$ & Private & $-31.1^{* * *}$ & $\begin{array}{l}\text { Filing Status and Deductions taken for HH's ZIP } \\
\text { CODE (Married omitted for Filing Status) }\end{array}$ & \\
\hline Head of Household filing status - female & $-11.1^{* * *}$ & Protective & 4.2 & Claim mortgage (share for zip code) & $2.2^{* * *}$ \\
\hline Number of Dependents & -0.04 & Service & 3.9 & Single filing status - male (share for zip code) & -0.2 \\
\hline Self-employed & $3.5^{* * *}$ & Farming & 2.5 & Single filing status - female (share for zip code) & $0.8^{*}$ \\
\hline Schedule E & $24.6^{* * *}$ & Crafts & $-19.7^{* * *}$ & Head of Household filing status - male (zip) & 0.9 \\
\hline Alternative Minimum Tax & $7.7^{* * *}$ & Operators & $-22.5^{* * *}$ & Head of Household filing status - female (zip) & 0.6 \\
\hline DC Plan & $4.4^{* * *}$ & Transportation / Materials & $-36.5^{* * *}$ & Number of Dependents (average for zip code) & $-1.0^{* * *}$ \\
\hline $\begin{array}{l}\text { Education across Household's Zip Code } \\
\left(1^{\text {st }}-8^{\text {th }} \text { Grade Education omitted }\right)\end{array}$ & & Laborers & 7.9 & Self-employed (share for zip code) & 0.4 \\
\hline Start high school & $-13.2^{* * *}$ & $\begin{array}{l}\text { Sector in HH's Zip } \\
\text { (For Profit omitted) } \\
\end{array}$ & & Schedule E (share for zip code) & -0.4 \\
\hline Graduate high school & -1.4 & Not For Profit & 4.9 & Alternative Minimum Tax (share for zip code) & $4.1^{* * *}$ \\
\hline Some college & $-6.5^{* *}$ & Local Government & $-13.0^{* * *}$ & DC Plan (share for zip code) & $2.6^{* * *}$ \\
\hline
\end{tabular}

Coefficients from specification (2) of Table 5 reported. ${ }^{* * *},{ }^{* *},{ }^{*}$ Significance at the 1 percent, 5 percent, and 10 percent levels, respectively. 